\title{
To What Extent Can Non-Native Speaker Teachers Teach Speaking Successfully in Foreign Language Learning Context?
}

\author{
Xinyi Yang" \\ Xi'an Eurasia University, Xi'an, Shaanxi 710065
}

\begin{abstract}
In this essay, non-native speaker teachers teaching speaking under the foreign language learning context would be analyzed. Instead of simply regarding native speaker teachers as the absolute priority in teaching speaking, non-native speaker teachers could also effectively impart speaking skills to students with their bilingual proficiency, second language learning experience and direct access to the cultural context of their students. After further studies, the unique competence of non-native speaker teachers would be revealed through this essay.
\end{abstract}

Keywords: Non-Native Speaker Teachers

\section{Non-native language teachers' oral skills in a foreign language learning environment}

First of all, with bilingual language proficiency, non-native speaker teachers would be more experienced to engage students to pursue speaking skills in the foreign language learning contexts. According to Medgyes (as cited in Kirkpatrick, 2007) ${ }^{[1]}$, since nonnative speaker teachers have gone through the same second language learning process as their students who are still dealing with, those teachers would anticipate most language learning difficulties their students would encounter during their foreign language studies. As is known to most foreign language learners, it is quite difficultly to ignore the gap between their mother tongue and their target foreign language. In order to narrow the gap, those foreign language learners have to transform not only their way of thinking but also their mother tongue language patterns to get used to a newly unfamiliarized thinking pattern and those target language symbols. Compared with those native speakers who are simply focused on their target language patterns, those non-native speaker teachers with their mastered mother tongue knowledge and their unique second language learning skills could help those students who are struggling with their second language studies. Under this circumstance, non-native speaker teachers would lead students to learn foreign language speaking in an effective way by intended converting students' way of thinking from mother tongue to target language and providing students with detailed as well as easy access to those difficult questions students might encounter during their studies. Besides, when students meet some complicated issues, teachers could explain to students in mother tongue. Step by step, students can be converted from their familiarized mother tongue to their unfamiliarized target language patterns.

\section{Non-native language teachers' understanding of the students' cultural background}

Copyright (C) 2020 Xinyi Yang

doi: 10.18282/1-e.v9i4.1735

This is an open-access article distributed under the terms of the Creative Commons Attribution Non-Commercial License (http://creativecommons.org/licenses/by-nc/4.0/), which permits unrestricted non-commercial use, distribution, and reproduction in any medium, provided the original work is properly cited.

less likely to fear confirming negative stereotypes of their group.

\section{References}

[1]Brief, A. P., \& Barsky, A. (2000). Establishing a climate for diversity: The inhibition of prejudiced reactions in the workplace. Research in Personnel and Human Resources Management, 19, 91-129; quoted in Roberson, L. \& Kulik, C. (2007), Stereotype threat at work, Academy of Management Perspectives, 21(2), 24-40.

[2]Spencer, S. J., Steele, C. M., \& Quinn, D. M. (1999). Stereotype threat and women's math performance. Journal of Experimental Social Psychology, 35, 4-28; quoted in Roberson, L. \& Kulik, C. (2007), Stereotype [11]threat at work, Academy of Management Perspectives, 21(2), 24-40.

[3]Roberson, L. \& Kulik, C. (2007), Stereotype threat at work, Academy of Management Perspectives, 21(2), 24-40.

[4]Schimel, J., Arndt, J., Banko, K. M., \& Cook, A. (2004). Not all self-affirmations were created equal: The cognitive and social benefits of affirming the intrinsic (vs. extrinsic) self. Social Cognition, 22, 75-99.

[5]Quinn, D. M., \& Spencer, S. J. (2001). The Interference of stereotype threat with women's generation of mathematical problemsolving strategies. Journal of Social Issues, 57, 55-71.

[6]Steele, C. M., \& Aronson, J. (1995a). Stereotype threat and the intellectual test performance of African-Americans. Journal of Personality and Social Psychology, 69, 797-811. 
Moreover, non-native speaker teachers' inherent awareness of local students' cultural context could also to some extent ensure students' effective learning of foreign language speaking. As the example noted by Holliday (as cited in Corbett, 2003) ${ }^{[2]}$, once some Egyptian university lecturers decided to replace the traditional styled classes with orers could explain to students in mother tongue. St 103), many students from strong uncertainty avoidance culture turn to show disrespect to the teacher, in that those students only recognize a teacher respectable when the teacher teaches in a traditional way. According to Cook (2005) $)^{[3]}$, compared with native speaker teachers, non-native speaker teachers are equipped with teaches in a traditional (p. 57). Under the same cultural background, non-native speaker teachers know exactly how to engage local students into effective speaking learning in students' preferred learning patterns and how to greatly attract students' participation in speaking practice activities in class. For example, second language learners from countries who are not accustomed to speaking in public would be better attracted in speaking classes with teachers coming from the same culture background. Based on their common culture basis, teachers would design some group collaborated tasks rather than some games or activities for fun or relaxation.

\section{Differences between mother tongue and non-native language}

While some would argue that native speaker teachers are more competent and qualified than non-native speaker teachers in language proficiency, fluency and native speakers owned ker teachers are more competent Kirkpartick, 2007, p. 184), it is still important to notice the fact that the ultimate aim in students' learning foreign language speaking is to learn how to use both their first language and target language effectively and accurately under different circumstances (Cook, 2005).Especially, students are not required to push themselves to follow the identical way in which native speakers express themselves. They are called the second or foreign language learners but not native speakers. The evaluation of their language skills should be focused more on their appliance of the vocabularies, sentence structures, as well as their reading and making some conversations. Based on that, non-native speaker teachers would still hold a competitive position in teaching speaking, compared with those qualified native speakers.

\section{Non-native language teachers can successfully teach oral English in foreign language learning}

In conclusion, based on non-native speaker teachers' bilingual capacity, precious foreign language learning experience and inherent awareness of local students' cultural context, it is fair to recognize the unique value of non-native speaker teachers in teaching speaking. Based on the current circumstance, it is inevitable for most students to be explored in foreign language studies. During their learning process, those second language teachers could integrate their personal bilingual learning tips into their class practice to help students to cope with the gap. Furthermore, compared with those native speaker teachers, their teaching methods are more suitable for students whose target language is the same as their mother tongue. In that case, their way of language teaching is more suitable for target language learning skills rather than the improvement of the second language skills. Their lack of the experience of thinking patterns as well as their cultural differences would be better understood and presented during their class practice. In a word, to some extent, non-native speaker teachers could teach speaking successfully in a foreign language learning context with their unique value. Second language learners' learning process will be more flexible and easier. In this way, students will be actively involved into foreign language learning in a more familiarized way. And their language learning difficulties will not be stressed or increased. This could lead to a more relaxing and interesting learning atmosphere and second language learners could also be maintained with their motivation and interest. Combined with bilingual cultural background, second language learning experience and tips, as well as the focused on language appliance, non-native speaker teachers would still play an effective role in foreign language speaking part.

\section{Reference}

[1]Cook, V. (2005). Basing teaching on the L2 user. In E. Llurda (Ed.), Non-native language teachers: Perceptions, challenges and contributions to the profession (pp. 47-61). New York, USA: Springer Science + Business Media, Inc.

[2]Corbett, J. (2003). An Intercultural Approach to English Language Teaching. Clevedon: Multilingual Matters.

[3]Kirkpatrick, A. (2007). World Englishes: Implications for International Communication and English Language Teaching. Cambridge: Cambridge University Press. 